Правительства РФ по вертикали в исполнительной власти, с высказыванием различных предложений ее совершенствования. Данными авторами предполагается дополнительное урегулирование порядка взаимодействия Российской Федерации и ее субъектов.

$$
* * *
$$

1. Конституция Российской Федерации" (принята всенародным голосованием 12.12.1993) (с учетом поправок)

2. Федеральный закон от 06.10.1999 N 184-Ф3 (последняя редакция) «Об общих принципах организации законодательных (представительных) и исполнительных органов государственной власти субъектов Российской Федерации» //Российская газета. - № 206.

3. Ведяшкин С.В. Охранительная функция административного права: концепт и реализация // Вестник. 2017. № 26. - С. 33-45.

4. Курдюк П.М., Очаковский В.А. Правовое регулирование взаимодействия органов государственного и муниципального управления // Изд-во «Эпомен»: Краснодар, 2019. - 90 с.

5. Лободина А. А., Шабунько Ю.А. Соотношение государственной и муниципальной службы как элементов единой системы публичной власти // Евразийский юридический журнал. 2020. - №5(144) - С. 145-146.

\title{
Шабунько Ю.А. \\ Коллизионные проблемы трудового права в современном международном частном праве
}

Кубанский государственный аграрный университет им. И. Т. Трубилина (Россия, Краснодар)

doi: 10.18411/trnio-01-2022-202

\section{Аннотация}

Современные трудовые правоотношения, осложненные иностранным элементом, содержат в себе большое количество актуальных вопросов, которые требуют к себе внимание со стороны представителей научного сообщества. Так, в указанной научной работе раскрываются наиболее злободневные пробельные аспекты и правовые пробелы, представленные в области коллизионного регулирования трудовых отношений в международном частном праве. Автор обращает особое внимание на сущность и правовую природу представленных проблем. Вместе с этим, в статье содержатся авторские предложения, направленные на скорейшее урегулирование коллизионных проблем, относящихся к трудовым правоотношениям в международном частном праве.

Ключевые слова: коллизионная норма, трудовое законодательство, трудовая деятельность, правовое регулирование.

\section{Abstract}

Modern labor relations complicated by a foreign element contain a large number of topical issues that require attention from representatives of the scientific community. Thus, in this scientific work, the most topical gap aspects and legal gaps presented in the field of conflict-of-laws regulation of labor relations in private international law are revealed. The author pays special attention to the essence and legal nature of the presented problems. At the same time, the article contains the author's proposals aimed at the early settlement of conflict of laws issues related to labor relations in private international law.

Keywords: conflict of laws rule, labor legislation, labor activity, legal regulation.

Как известно, трудовое законодательство обладает сложной правовой природой и специфическим характером. Необходимо учитывать то обстоятельство, что современное трудовое право является комплексным, то есть в его содержании присутствуют нормы как публичного, так и частного характера.

Стоит сказать о том, что в любом государстве существует сформировавшееся трудовое законодательство, которое направлено на регулирование отдельно взятых правоотношений. Однако, следует учитывать тот факт, что в большинстве случаев трудовые 
отношения, осложненные иностранным элементом, регулируются нормами того государства, в рамках которого был заключен трудовой договор, a также непосредственно осуществлялись трудовые функции.

В рамках поднятой тематики необходимо сказать о том, что современная правовая доктрина содержит в себе определенные проблемные аспекты, которые, в свою очередь, возникают ввиду коллизионного регулирования трудовых правоотношений, в которых может участвовать иностранное лицо. К наиболее существенным проблемам необходимо относить следующее.

- Отсутствие какого-либо теоретического подхода, направленного на определение отраслевой принадлежности тех норм, которые посвящены правовой регламентации трудовых правоотношений.

- Относительно низкий уровень правового регулирования, а также конструкции института публичного порядка, связанного с международными трудовыми отношениями.

- В национальном трудовом законодательстве многих государств попросту отсутствуют коллизионные правовые положения.

- Также необходимо сказать о проблеме, представленной в качестве отсутствия официального и согласованного толкования, так называемого, принципа национального режима. Данная проблема является весьма актуальной, так как указанный принцип используется в рамках процедуры унификации тех правовых норм, которые направлены регламентацию трудовых отношений на международной арене.

Стоит сказать о том, что представленные выше проблемные аспекты возникают вследствие определенной неоднозначности толкования отраслевой принадлежности международных трудовых правоотношений. Данную точку зрения разделяют многие правоведы и практикующие специалисты.

Необходимо акцентировать внимание на том, что коллизионные проблемы правового регулирования трудовых отношений в международном частном праве возникают также и ввиду того, что в настоящее время активизировались миграционные потоки, которые явились побудителем возникновения новых трудовых правоотношений. На основании этого, можно с уверенностью сказать о наличии необходимости поэтапного реформирования и модернизации системы коллизионного регулирования отношений в трудовой сфере с участием иностранного элемента. По нашему мнению, одним из способов разрешения представленной выше проблемы может являться унификация права. То есть, сближение правовых систем различных стран, в том числе и в сфере трудового законодательства, повлечет за собой формирование единых механизмов правового регулирования, не говоря уже об уменьшении всяческих противоречий, которые могут возникать на практике.

При изучении поднятой в данном научном исследовании тематики, необходимо обратить внимание на такое понятие как «экстерриториальность». В международном частном праве экстерриториальность выступает как особый критерий, который может применяться к трудовым правоотношениям. Данный критерий имеет место в тех случаях, когда в качестве субъектов трудовых правоотношений выступают российские граждане, однако непосредственно сама трудовая деятельность реализуется ими за территорией нашего государства.

Подобного рода правоотношения являются результатом, так называемой, дифференциации регулирования трудовых отношений. Свое правовое отражение указанные выше отношения находят в нескольких нормативно-правовых актах. В качестве первого выступает гл. 53 ТК РФ, в содержании которой предусматривается правовое регулирование труда работников, которые осуществляют трудовые обязанности в консульстве или же 
дипломатическом представительстве. Сюда же относится выполнение трудовых функций российскими гражданами в государственных учреждениях, находящихся за территорией нашего государства. В качестве второго нормативного акта необходимо отнести КТМ РФ, согласно которому трудовое законодательство распространяется как на российских граждан, так и на иностранных лиц, которые выполняют трудовые функции, находясь на судне, плавающем под российским флагом. Исходя из положений представленных нормативноправовых актов, можно с уверенностью сказать о том, что специальному коллизионному правовому регулированию подвергаются только отдельные категории граждан, которые осуществляют трудовые обязанности в государственных органах, консульствах, представительствах, а также морских судах. Безусловно, подобная ситуация является крайне негативной, так как коллизионная регламентация трудовых отношений должна распространяться на все категории работников, связанных с осуществлением трудовой деятельности за рубежом.

На основании представленных выше фактов, очевидным представляется то, что правовое регулирование трудовых отношений с участием иностранного элемента содержит в себе несколько проблемных аспектов и даже правовых пробелов. В заключении настоящему исследованию сформируем несколько предложений, которые поспособствуют разрешению коллизионных проблем, присущих трудовым правоотношениям в современном международном частном праве. Так, по нашему мнению, разрешения всех проблемных вопросов и восполнения представленных выше пробелов можно добиться путем изменения действующего ТК РФ. Так, в его содержание необходимо включить положения, которые предусматривали бы применение к трудовым отношениям, в которых участвует иностранное лицо, шестого раздела ГК РФ. То есть, по сути применять принцип аналогии. Например, по мнению некоторых авторов, к указанным правоотношениям следует применять такой юридический способ как аналогия права и аналогия закона.

Вместе с этим, необходимо сказать о том, что отечественная правовая система не предусматривает в своем содержании специального нормативно-правового акта о международном частном праве. Таким образом, существует необходимость во включении в действующую редакцию ТК РФ коллизионных норм, направленных на более эффективное регулирование трудовых правоотношений, в которых может участвовать иностранный элемент. Если говорить подробнее, то по нашему мнению, следует включить, например, принцип автономии воли. Представленный принцип позволит сторонам трудового договора принимать самостоятельное участие в выборе права, применяемого к их трудовым правоотношениям. Указанная возможность поспособствует более эффективной защите их прав и законных интересов.

$* * *$

1. Карасева Л.В. Значение норм международного частного права в регулировании трудовых отношений мигрантов из стран СНГ в РФ: дис. ... канд. юр. наук. М., 2007.

2. Трудовой кодекс Российской Федерации от 30 декабря 2001 г. № 197-Ф3 // Собрание законодательства Российской Федерации от 7 января 2002 г. № 1 (часть I) ст. 3.

3. Кодекс торгового мореплавания Российской Федерации от 30 апреля 1999 г. № 81-Ф3 //Собрание законодательства Российской Федерации от 3 мая 1999 г. № 18 ст. 2207.

4. Протасова А.С. Коллизионное регулирование трудовых отношений, осложненных иностранным элементом: проблемы и перспективы // Вестник БГУ. 2011. № 2.

5. Гражданский кодекс Российской Федерации от 30 ноября 1994 г. № 51-Ф3 // Собрание законодательства Российской Федерации от 5 декабря 1994 г. № 32 ст. 3301.

6. Кудрявцева Л.В. Значение норм международного частного права в регулировании трудовых отношений мигрантов из стран СНГ в РФ: М-во образования и науки РФ, Российский гос. социальный ун-т, фил. в г. Анапе Краснодар, 2011. 